\title{
Lexical Diffusion and Gramaticalization: The Case of Tibetan slob sbyong byed
}

\author{
Chin-Wen Huang \\ Department of Chinese Language and Literature, National Chi Nan University, Taiwan
}

Copyright $\bigcirc 2017$ by authors, all rights reserved. Authors agree that this article remains permanently open access under the terms of the Creative Commons Attribution License 4.0 International License

\begin{abstract}
Lexicalization and grammaticalization are two of the most important processes in linguistic change (Laurel and Traugott, 2005 ${ }^{[1]}$; Hopper and Traugott, 2003 ${ }^{[2]}$ ). Spoken Standard Tibetan (SST) offers an example of both these processes applying sequentially to the phrase slob sbyong byed, 'to study; to learn.' This phrase is an instance of a full verb byed becoming a light verb (grammaticalization) after compounding (lexicalization). In Tibetan, three light verbs: byed, rgyag and gtong compete lexically. This lexical competition can be treated under the Lexical Diffusion Theory proposed by Wang $\left(1969^{[3]}\right.$; $\left.1979^{[4]}\right)$.
\end{abstract}

Keywords Historical Linguistics, Lexicalization, Grammaticalization, Lexical Diffusion Theory

\section{Grammaticalization, Analogy, and Lexical Diffusion}

Grammaticalization is a process in which "lexical items and constructions come in certain linguistic contexts to serve grammatical functions and, once grammaticalized, continue to develop new grammatical functions" (Hopper \& Traugott $2003,231-3)^{[2]}$. This is usually attributed to cognitive factors, which play an important role in all changes in components of grammar. The primary cognitive motivors of change are usually said to be analogy and reanalysis (Milroy 1992:172 $)^{[5]}$. According to Murray (1996:252) ${ }^{[6]}$, “Analogy reflects the preference of speakers for regular patterns over irregular ones. It typically involves the extension or generalization of a regularity on the basis of the inference that if elements are alike in some respects, they should be alike in others as well."

Another important concept in the cognitive view of lexicalization and grammaticalization is the idea of "constructions." Bybee $(2006: 716)^{[7]}$ defines these as "partially schematic, conventionalized sequences of morphemes with a direct semantic representation." Thus, grammaticalization is the creation of a new grammatical morpheme and a new construction out of an old construction.

Constructional change is usually related to frequency. An existing lexical item becomes more frequent, sometimes changes in various ways, and becomes a new construction.

According to Bybee $(2006: 717)^{[7]}$, constructions arise and change over time due to exemplar representations and exemplar clusters. Exemplar representations "allow specific information about instances of use to be retained in representation" and also "provide a natural way to allow frequency of use to determine the strength of exemplars." Exemplar clusters "are organized in terms of members that are more or less central to the category, rather than in terms of categorical features."

This leads Bybee to emphasize the effects of repetition or frequency on constructions. In her view, low repetition leads to "conventionalization only" (such as idioms), while high repetition "can lead to the establishment of a new construction with its own categories," and extreme high frequency leads to "the grammaticization of the new construction, the creation of grammatical morphemes, and changes in constituency."

The effects of repetition thus promote one construction changing to another through exemplar representation. But how do the representations change? This paper adopts a mechanism previous limited to phonetic and lexical change: lexical diffusion theory. Scholars have debated the Lexical Diffusion Theory from a variety of perspectives (Milroy

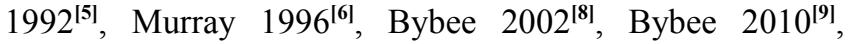
Kiparsky $\left.2008^{[\mathbf{1 0}]}\right)$. The basic concept, as proposed by Wang $(1979)^{[4]}$ is that changes in sound systems proceed word by word. Labov $(1981: 296)^{[11]}$ found that there were two types of sound change, one of which he agreed was a type of lexical diffusion. Kiparsky (2008) ${ }^{[10]}$ however argued that lexical diffusion was similar to lexical analogy in 'every respect.' The table below (from Kiparsky 2008:4) ${ }^{[\mathbf{1 0 ]}}$ illustrates how lexical analogy and lexical diffusion are rules, generalized and spreading out item by item. 
Table 1. lexical analogy and lexical diffusion

\begin{tabular}{|c|c|c|c|c|}
\hline & Sound change & Borrowing & Lexical analogy & Lexical diffusion \\
\hline Generality & across-the-board & item by item & $\begin{array}{l}\text { context by context, } \\
\text { item by item }\end{array}$ & $\begin{array}{l}\text { context by context, } \\
\text { item by item }\end{array}$ \\
\hline Gradience & gradient & quantal & quantal & quantal \\
\hline Origin & endogenous & contact & endogenous & endogenous \\
\hline Rate & rapid & rapid & slow & slow \\
\hline Effect on: & & & & \\
\hline rule system & new rules & no change & rules generalized & rules generalized \\
\hline sounds/phonemes & new inventory & peripheral & no change & no change \\
\hline vocabulary & no change & new words & no change & no change \\
\hline
\end{tabular}

This paper focuses on the following issues:

(i) The morphological function of the Tibetan light verb byed, and its use in constructions such as slob sbyong byed 'to study' ${ }^{\text {iii }}$.

(ii) The historical development of byed from its original function as a volitional verb modulating the main predicate of a clause.

(iii) The similarity between grammaticalisation and lexical diffusion.

(iv) The problem of 'residue' in grammatical change.

\section{Light Verb Constructions in Tibetan}

\subsection{Light Verbs}

Light verb construction is composed by two verbs, the major verb is the main semantic and grammatical vehicle and the other is minor in semantic and grammatical. The function of light verbs is to modulate the event predication of a main predicator in the clause. Different light verbs will do so in different ways and some of the semantic contributions are quite subtle. A light verb is thus sometimes described as having more 'semantic content', than auxiliary verbs. Specifically, Tibetan adds the light verb byed to provide an active sense (Jäschke 1883:43) ${ }^{[12]}$.

A light verb construction (Butt 1993 ${ }^{[13]}$, Bickel and Nichols 2001 $1^{[14]}$, Tantos $2008^{[15]}$, Seiss 2009 $9^{[16]}$, Butt 2010 $0^{[17]}$ ) modulates a given event predication, but does not supply its own event. For example, it may provide additional information about event details such as what, who, or how the event occurs. It does not function as tense or aspect do, to situate a given event with respect to speech or reference time, but can add syntactic information, such as passive voice about an event.

Most verbs in Lhasa Tibetan are multisyllabic forms composed of a predicative noun and a light verb. Thus Simon and Hill (2015: 387-388) ${ }^{[18]}$ find that honorific verbs are constructed with the honorific counterpart of the predicative noun and the honorific form of the light verb. The honorific light verb gnan is appended to the verb for one which lacks a lexical honorific equivalent. Since there is a strategy to mark honorific verb by adding an honorific light verb, it provides an internal motive for verb-verb compounds and construction.

Trisyllabic light verb constructions are typical verbal compounds in SST, composed of a disyllabic noun (or adjective) and a final light verb (Jäschke $1883^{[12]}$; Wolfenden 1929 ${ }^{[19]}$; Goldstaid 2001 ${ }^{[20]}$; Vokurková 2008 ${ }^{[21]}$; Simon \& Hill 2015 $5^{[18]}$; Zhao et al. 2016 $6^{[22]}$ ).

Table 2. Examples of light verbs

\begin{tabular}{|c|c|c|c|c|c|}
\hline ID & Light Verb & Occurrence Number & ID & Light Verb & Occurrence Number \\
\hline 1 & डे & 1027 & 2 & 牾 & 569 \\
\hline 3 & ๒ & 134 & 4 & 咩 & 111 \\
\hline 5 & 羊好 & 109 & 6 & 5,5 & 84 \\
\hline 7 & सेक्य & 70 & 8 & क前 & 61 \\
\hline 9 & 端叫 & 49 & 10 & चबग & 46 \\
\hline
\end{tabular}

Light verbs have evolved from volitional verbs (Jäschke 1883:50) ${ }^{[12]}$. Taking gtong, byed, and rgyag as examples, Table 2 above is adopted from Zhao et al. (2016:139) ${ }^{[22]}$. As the database shows that byed (as 1027 tokens) and rgyag (as 569 tokens) are the most frequently used according to the word-occurrence.

\subsection{Tibetan slob sbyong byed as a Light Verb Construction}

In SST, slob sbyong byed means 'to study'. There are several meanings in Tibetan for the word slob-pa; its primarily meanings are 'to learn' or 'to teach' and its main nominal meaning is 'lesson'. The form sbyong also means 'to learn.' It may seem unnecessary to combine these three forms to provide a compound with a meaning which the components already express. Why combine lob(-pa) 'to learn/teach', plus sbyong(-ba) 'to learn', plus byed (-pa) 'to cause' to create a compound which is synonymous to both its components, slob and sbyong? But this is what Tibetan does. In the examples below, Jäschke $(1881: 587)^{[23]}$ and Zhang $(1993: 2999)^{[24]}$ both list 1 to 3; 4 comes from Goldstein $(2001: 199)^{[20]}$. 


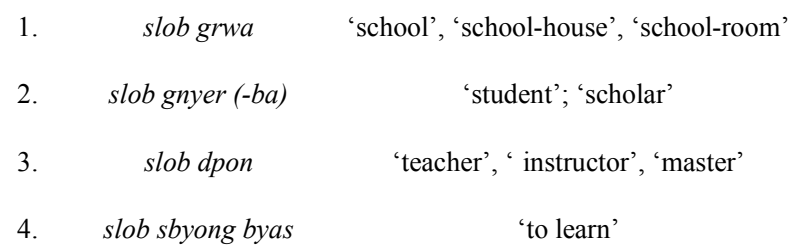

Jäschke $(1881: 405)^{[23]}$ explains the word sbyong $(-b a)$ as 'to exercise, to practice; to study'. Zhang (1993: 2026-7) ${ }^{\text {[24] }}$ states that sbyong (-ba) is a transitive verb meaning 'to learn, to practice, to imitate', items 5 and 6 are from Zhang (1993: 2027) ${ }^{[24]}$. Vokurková $(2008: 301)^{[21]}$ states sbyong using as a main verb also :

\begin{tabular}{|c|c|c|}
\hline 5. & yu ge sbyong ba & 'to practice to write' \\
\hline 6. & sbe ga sbyong ba & 'to practice to wrestle' \\
\hline & gya skad sbyangs 'dod & 'want to learn Chinese \\
\hline
\end{tabular}

The form byed $(-p a)$ is also typically a transitive verb in Written Tibetan. According to Jäschke $(1881: 378)^{[23]}$, in most contexts, byed(-pa) means ' To make, to fabricate, to cause, to effect.' Inflected forms for byed include 'to cause (present)', byas 'to cause (past)' and bya 'to cause (future).'

$$
\begin{aligned}
& \text { byed (-pa) } \quad \text { effect; } 2 \text {. to say, to call; } \\
& \text { 3. to go away, to disappear' }
\end{aligned}
$$

\subsection{Light Verb Construction}

The morpheme byed occurs in many compounds and phrases in SST. The examples below (9-22) come from $\mathrm{Yu}$

\begin{tabular}{|c|c|c|}
\hline 9. & slob sbyong byed & 'to study' \\
\hline 10. & sems khur byed & 'to concern' \\
\hline 11. & gzab gzab byed & 'to be careful; carefully' \\
\hline 12. & ngo rgol byed & 'to object' \\
\hline 13. & gra sgrig byed & 'to prepare' \\
\hline
\end{tabular}
(1983). ${ }^{[24]}$

\begin{tabular}{|c|c|c|}
\hline 14. & yo bseng byed & 'to correct' \\
\hline 15. & yid smon byed & 'to admire' \\
\hline 16. & lag len byed & 'to practice' \\
\hline 17. & gshags bcon byed & 'to have an operate' \\
\hline 18. & nan dah byed & 'to work hard' \\
\hline 19. & mphong chung byed & 'to despise' \\
\hline 20. & lta rtog byed & 'to take care of' \\
\hline 21. & kha rtsod byed & 'to quarrel' \\
\hline 22. & khag khag byed & 'to depart' \\
\hline
\end{tabular}

In these examples, the first two syllables are nominal compounds which become verb phrases by adding byed as the last syllable. This demonstrates that byed is a productive morpheme, expressing an active, causative meaning (Jäschke 1883:43) ${ }^{[\mathbf{1 2 ]}}$. It is inflected for tense, including byed 'to cause (present),' byas 'to cause (past),' and bya 'to cause (future).' The most common forms are byed or byas. Its use in tense modulation, but relative lack of lexical content mark byed as a typical light verb.

In fact in most of these constructs, both the first two elements are also independent verbs. For example, in slob sbyong byed 'to study', both slob and sbyong are verbs. When combined together, they still function as a verbal construction. Through lexicalization, we can see the logic behind this process.

\subsection{From Volitional Verb to Light Verb}

The use and function of byed in Old Tibetan (OT), however, differs from what we found above. OT byed is still a transitive and volitional verb, according to Li and Coblin $(1996)^{[26]}$. There are several different morphological forms of byed (-pa) in OT: 
23

$$
\text { byed(-pa) to make, to produce, }
$$$$
24 \quad \text { byed byed (-pa) }
$$

'to keep making'

The continuing form of byed-pa

'made, to be, caused to be, (The perfect tense of byed-pa)

to make, to cause
II,S L 14 /N L 57

VII,W L 30/E L 29

VIII, L 22

IX, L 41.43

XII, L 2

II,S L 7

VII,W L 9.17.19 /E L 15

XIII, L 2

I,W L 8.67.69 /E L 31.70

II,E L 16 /S L 4.41.60.72.74

VI, L 56.57

VII, L 5.6.8.13.15.16.17.38.51 /E L 14

VIII, L 33

IX, L 44

I,W L 20.45.46 /E L 30

VI, L 19

VII,W L 13.25.25-26/E L 32.39

IX, L 42

OT byed in example 23 is a true volitional verb because two morphological forms of the verb are found everywhere. Byas in example 25 is a perfect form and bya (-ba) in 26 is a causal or future form. Byed-byed (here byed-byed-pa) in 24 is a duplicate form with the meaning of continuing or repeating. This indicates that byed was a transitive verb at least from 763 A.D. $~ 822$ A.D. Light verbs are typically idiomatic, frozen forms that do not have complex paradigms. Since we find byed has does, it was not yet a light verb in this period.

Two important steles from this period both include a full range of paradigmatic forms for byed: the 'XUE BEI' and the 'TANG FAN HUI MENG BEI':

Table 3. Morphological forms of byed in 'XUE BEI' and 'TANG FAN HUI MENG BEI'

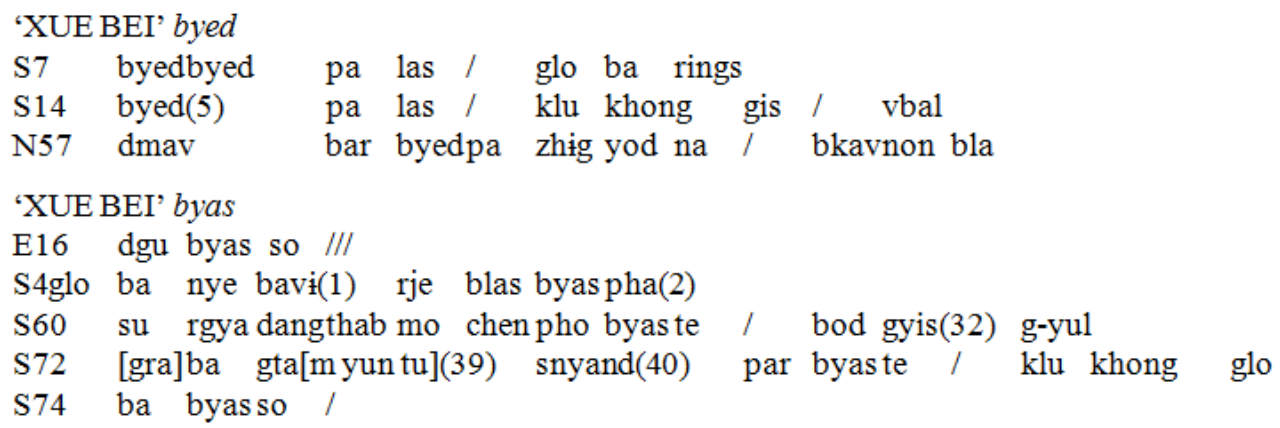

'XUE BEI' bya (no instances)

'TANG FAN HUIMENG BEI' byed (no instances)

'TANG FAN HUIMENG BEI' byas

W8 lha myi kun [gyis] shes(7) shing dpang byas(8)

W67 gtsigs(78)vdi bzhin du ma byas(79) sam

W69 pa la sdig cing // lan du ku dku sgyu(81) ci byaskyang

E31 do va $\operatorname{dag}(65)$ gi tshe(66) // dmag stongs kyis phanthogs par byaspa dang// phantshun

E70 ......byas(132) so // gtsigs khrims(133) rdo ringsla bris ...(134)

'TANG FAN HUIMENG BEI' bya

W20 skyid par bya ba la ni dgongs pa gcig(26)/

W45 bya // tseng shu hywan(51) du bod dangphrad pa

W46 yan cad ni bod kyis(52) phu dud bya ste//

E30 dag mgulgyis(62) kyang // gnyen bavi [ch]ab(63) gangdu bya ba // thugs brel che nas(64) 
In 'XUE BEI' and 'TANG FAN HUI MENG BEI', the function and use of byed is thus a full verb. Since byed behaves like a normal transitive verb here, there is no lexical freezing at all. We found no examples of morphological freezing or lexical synonyms. This means that the grammatical and lexical changes occurred later, sometime in the period that separates 'XUE BEI' and 'TANG FAN HUI MENG BEI' from Modern Tibetan.

\section{Grammaticalization and Lexical Diffusion}

\subsection{Idiomaticization and Opaqueness in Compounds}

Brinton and Traugott (2005: 49) ${ }^{[27]}$ found that combinations in an earlier stage may have resulted from extensive phonological reduction and semantical opaqueness, while in recent stages it may be more transparent semantically and morphologically. Since we do not see much opaqueness, these terms may be considered "idioms."

Though it is difficult to define idiomaticization, Brinton and Traugott (2005:55) ${ }^{[27]}$ mention three features:

Table 4. Brinton/Traugott features of idiomaticization

(a) Semantic opacity or noncompositionality

(b) Grammatical deficiency

(c) Lack of substitutability

Idiomaticization is associated with routinization and simplification. Of course it is very difficult to deduce the meaning of an idiom. Even the synonymous lexical items can never be substituted. Nor does an idiom allow the characteristic syntactic variability and meanings found in free combinations. This means that no grammatical variations are allowed, such as positive to passive, affirmative sentence to negative sentence, or topical transitions. However, the idiom itself was just frozen.

We believe that there must have been two-step process in the formation of compounds such as slob sbyong byed. The first is compounding, and the second is light-verb attaching. At the beginning, slob combined with the synonymous sbyong to form a compound word. This is also frequent in Chinese, for example, where phrases such as 將 + 軍 'an admiral', 司 + 令 'a commander', 統 + 帥 'a commander', all once functioned as separate verbs, but later compounded and came to be nouns as eventually. This is similar to the case of Tibetan using the synonyms slob sbyong as a noun. The change of categories in compound forms is called "eccentric." Zhang (1993: 3000) ${ }^{[24]}$ provided the following two examples. Byed-pa in the final position of the sentences are the verb, then slob sbyong are the noun.

The second step is to use byed-pa in the final position to be a light verb. This is comparable to the formation of honorifics where the main verb honorifics add a light verb (see section 2.1, p.3-4). Just as a main construction gets honorific feature through expanding a light verb with honorifics, a main construction gets the causative feature by expanding a light verb with the causative.

Then the meanings of example $23 \& 24$ are somehow different from the exactly meaning of byed-(pa) as a real and main verb in example 8 , there are the causative feature left only.

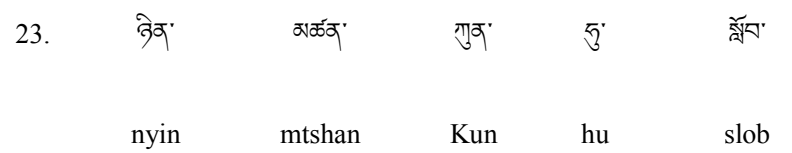

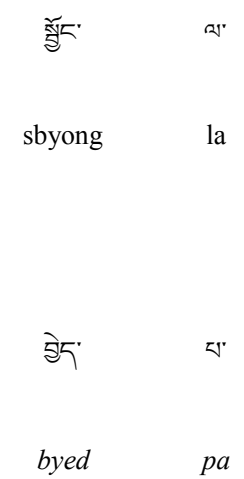




\subsection{Trisyllabic Light Verb Constructions in SST}

In SST, "verb - verb" compounds are frequent. They may be divided into two types, based on their function: nominals (type 1), and verbals (type 2). Instances of type 1 compounds previously mentioned include (25b) rogs skyor byed 'to support', and (26b) snyeg rdeg byed 'to hit'. Thus, rogs 'to be a friend' plus skyor, 'to support', became rogs skyor 'help' as in example 25a, and adding byed turns rogs skyor into a verb as in $25 b$.

In example 26b, snyeg 'to promote' plus rdeg 'to harm' became snyeg $r d e g$ 'hit' as in 26a. This process was repeated when byed turned snyeg rdeg into a verb. Note that gtong has the same function as byed, in that is also turns snyeg rdeg into a verb of the same meaning, as shown in example 26c. This means that two different light verbs, byed in 26b, and gtong in 26c, perform equivalent functions and form synonymous compounds, despite their original differences.

The pairs byed in 26b and gtong in 26c, and rgyag in 27b and byed in $27 \mathrm{c}$ demonstrates how these three different light verbs have the same function. All three verbs: byed, gtong, rgyag, when occuring in the final position mark the construction as verbal with a causative sense, with no significant differences between them.

$\begin{array}{llc}\text { 25a. } & \text { rogs skyor } & \text { 'help' } \\ \text { 25b. } & \text { rogs skyor byed } & \text { 'to support' } \\ \text { 26a. } & \text { snyeg } \text { rdeg } & \text { ' hit' } \\ \text { 26b. } & \text { snyeg } \text { rdeg byed } & \text { 'to hit' } \\ \text { 26c. } & \text { snyeg } \text { rdeg gtong } & \text { 'to hit' } \\ \text { 27a. } & \text { kha snon } & \text { 'addition' } \\ \text { 27b. } & \text { kha snon rgyag } & \text { 'to add' } \\ \text { 27c. } & \text { kha snon byed } & \text { 'to add' }\end{array}$

Examples $26 \mathrm{bc}$ and $27 \mathrm{bc}$ have the same derivational-like function, i.e., gtong has the same function as byed, and changes a nominal compound into a verb. As we see, 26a changes into $26 \mathrm{~b}$ and $26 \mathrm{c}$, and $27 \mathrm{a}$ changes into $27 \mathrm{~b}$ and $27 \mathrm{c}$. Examples b and $c$ of the pairs are equal. Since this is a kind of light verb attachment, both examples $26 \mathrm{bc}$ and $27 \mathrm{bc}$ show that the three verbs, rgyag, byed and gtong have the same function: changing nominal forms into verbal constructions.

Table 5. byed, rgyag and gtong

\begin{tabular}{|c|c|c|}
\hline डे & byed-pa & 'to make, to fabricate' or ' to cause, to effect' \\
\hline 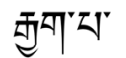 & rgyag-pa & 'to throw, to cast, to fling' \\
\hline 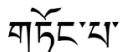 & gtong-pa & 'to let go, to dismiss' \\
\hline
\end{tabular}

In Written Tibetan, rgyag, byed and gtong are distinct transitive verbs. According to Jäschke $(1881: 378)^{[23]}$, byed-pa means 'to make, to fabricate' or ' to cause, to effect', rgyag-pa means 'to throw, to cast, to fling' (1881:106) and gtong-pa means 'to let go, to dismiss' (1881:208).

The use of verb-verb compounds to form compounds is also common in Chinese, such as 幫 + 助 'to help', 動 + 搖 'to be faltered'. Here, the two elements combine to form a verb. We can also see the 'Noun + Noun', 'Adj. + Adj.', and even 'Hand + Modifier' forms. Take 28 for example, type 2 in Mandarin Chinese 幫助 may be structurally defined as a noun at times.

\section{8. 我給了他一點幫助}

'I give him a bit of help.'

The distribution of nominal 幫助 'help' is limited; it serves as a verb under most conditions. In addition, there are many nominals compounds composed of verbal elements in Tibetan. However, they are used as a noun when combined together anyway. The pairs in 29 to 35 serve as examples:

\begin{tabular}{|c|c|c|}
\hline $29 a$. & bkag sdom & 'forbidden' \\
\hline $29 b$. & bkag sdom byed & 'to forbid' \\
\hline 30a. & bkod sgig & 'arrangement' \\
\hline $30 \mathrm{~b}$. & bkod sgrig byed & 'to arrange' \\
\hline $31 \mathrm{a}$. & rkun tshang & 'resort of thieves' \\
\hline $31 \mathrm{~b}$. & rkun tshang byed & 'to harbor a criminal' \\
\hline 32a. & lkog mthun & 'collusion' \\
\hline $32 \mathrm{~b}$. & lkog mthun byed & 'to collude with' \\
\hline $33 a$. & kun sphyod ther & 'rectification' \\
\hline $33 b$. & kun sphyod ther byed & 'to rectify' \\
\hline $34 a$. & krog krog & 'showing off' \\
\hline $34 \mathrm{~b}$. & krog krog byed & 'to show off' \\
\hline $35 \mathrm{a}$. & diar sbyong & 'vegetarian diet' \\
\hline $35 \mathrm{~b}$. & dkar skyong byed & 'to be a vegetarian' \\
\hline
\end{tabular}

In these examples, the a-word in pairs 29 35 is a noun; in contrast, the b-word is in each case a verb formed by attaching the light verb byed. All the a-words are nominal compounds, while all the b-words are verbalized phrases.

\subsection{Grammaticalizaton and Verbal Synonymy}

Let us discuss the grammaticalizaton process seen in the case of byed. The process of attaching a light verb marks a 
phrase are verbal, or a verbal form of a noun. This is a grammatical issue.

$$
\begin{aligned}
& \text { 21. kha rtsod byed 'to quarrel' } \\
& \text { 36. ngo rgol byed 'to object' }
\end{aligned}
$$

In example 21, we saw that rtsod means 'to quarrel'. However, when the two elements, kha 'mouth' and rtsod 'to quarrel' are compounded, the resulting kha rtsod is a nominal compound. When byed is compounded with kha rtsod, the result is again verbal phrase. This means that kha rtsod is more predominate rather than rtsod. As to as example 21, rgol from example 36 means 'to dispose, to object'. There is no need to mention ngo 'face' again. However it is used again, and the compound output is considered as a noun. Moreover, the light verb attaching of byed makes ngo rgol a verb phrase.

Most of the languages in the world use reduplication to add stress. Take South Min (a dialect of Chinese) for example, ang21 ang24 'redder' imply a greater degree of red than a single character and the syllable ang 24 'red'. The most interesting thing is that they are duplicated three times in South Min, therefore ang2 ang21 ang24 implies the greatest degree, or 'the reddest'. Of course when the reduplications are applied, tone-sandy takes place as well, just as when all two or three syllable words are combined. Examples 22, 34b and 37 are three cases of reduplication.

$$
\begin{aligned}
& \text { 22. khag khag byed } \\
& \text { 34b. krogkrog byed } \\
& \text { 37. gzab gzab byed to show off' }
\end{aligned}
$$

Reduplication happens often in Tibetan. In the case of 22, khag is a noun which means ' part, division, section'. The reduplicated form khag khag 'distinct' is found in Zhang $(1993)^{[24]}$ but not in Jäschke $(1881)^{[23]}$. Then the byed is attached to khag khag in the end to output a verb khag khag byed 'to depart'. In example 37, gzab-pa means 'to treat well', and originally gzab gzab byed pa means 'to treat somebody complaisantly'. In the compound form, the meaning becomes 'to treat with much care'.

In the case of $34 \mathrm{~b}, k r o g$ does not appear in Jäschke $(1881)^{[23]}$, but the reduplicated form krog krog does in Zhang (1993:40) ${ }^{[24]}$ with the meaning ' have one's nose in the air'. Interestingly, it may also have another meaning: 'the sound of knocking the wood as a bird'. If a verb is needed, gtong, not byed, must be used, as in example 38 in Zhang ${ }^{[24]}$.

$$
38 \quad \text { sgo la krog krog gtong ba }
$$

'to knock the door with the sound just like a bird does'

This important hint shows the distinction between byed and gtong. They are different verbs indeed, and the development of identical or some kind of merging must have taken place recently. In written Tibetan, rgyag, byed and

gtong are all different transitive verbs. Please review Table 5 in section 3.2.

However the development of identical or merged light verbs must have taken place recently. In particular, byed-pa used to be an agent which was able to set up an action, since byed-pa was the performer or instrument in these contexts. This is called 'the instrument case' in Jäschke (1881:378) ${ }^{\text {[23] }}$ and Zhang (1993:1893) ${ }^{[24]}$. At the time, byed-pa was used as a case marker in the past.

Within the scope of this study, we do not see much difference between two of these three, but the processes by which these three forms were attached to form verbal compound are well worth examining.

\subsection{From Lexical Diffusion to Grammatical Change}

Grammaticalization usually refers to the change whereby lexical items and constructions to serve grammatical function and continue to develop new grammatical function, as stated in Hopper (2003). A lexical item brings much semantical meaning, while a grammatical one carries less semantical meaning but more grammatical information. However, light verbs have a dual function, both semantic and grammatical. They are more likely syntactically in which verbal features such as causative or honorific are needed to express. From this point of view, the byed attaching is taken to express a grammatical event.

Brinton and Traugott (2005) $)^{[27]}$ discuss several approaches to lexicon survey. One of those is to claim individual lexical items are the language-particular representations of many components. But it is waiting for examination yet. Such as how many units there are in the lexicon, how many the combinatorial possibilities they allow, or if there are concrete and relational concepts proposed by Sapir or not.

Somehow the causative component of three light verbs byed, rgyag, and gtong are recognized. And there is a tendency to change all these three light verbs the same grammatical function and semantics meaning.

39.

$$
\begin{aligned}
& \text { khrel gad byed } \\
& \text { khrel gad rgyag 'to sneer at, to laugh at' }
\end{aligned}
$$

40.

gad 'phyid byed
gad 'phyid rgyag 'to clean up'

41.

$$
\text { mngag rdzong byed }
$$

mngag rdzong gtong

$$
\text { grogs po byed }
$$

'to make friend (with)'

grogs po gtong$$
\text { 'to make friend (with)' }
$$ 
Since there are no more semantical and grammatical differences in these cases, they are synonyms. Wang $\left(1969^{[3]}\right.$, $1979^{[4]}$ ) proposed a theory of lexicon diffusion. The lexicon diffusion theory argues that sound change is phonetically abrupt and lexically gradual, which is the opposite of sound change of the neogrammarian type. The main assumption of lexicon diffusion theory is that not all lexicon items are affected by a sound change at the same time. Instead, change advances gradually, item by item. Since change occurs morpheme by morpheme, item by item, or step by step, if we take a look at the middle of the change process, we find something similar to the model provided by Wang $(1979: 362)^{[4] \mathrm{iii}}$.

Table 6. The competing of unchanged variety $(\mathrm{Wx})$ and changed variety $(\underline{\mathrm{Wx}})$

\begin{tabular}{c|ccc}
\hline Words & & & \\
\hline $\mathrm{W}_{1}$ & & $\mathrm{u}$ & $\mathrm{c}$ \\
$\mathrm{W}_{2}$ & & $\mathrm{~W}_{2} \sim \overline{\mathrm{W}}_{2}$ & \\
$\mathrm{~W}_{3}$ & & $\mathrm{~W}_{1} \sim \overline{\mathrm{W}}_{3}$ & \\
$\mathrm{~W}_{4}$ & & & \\
$\mathrm{~W}_{5}$ & $\mathrm{~W}_{4}$ & & \\
\hline
\end{tabular}

Table 6 is an earlier model of lexicon diffusion which illustrates all following studies; it is a paradigm. We see lexical items $\mathrm{W} 1$ to $\mathrm{Wn}$ which are processing change. In stage 1: W1 is already effected and replaced. In stage 2, the varieties $\mathrm{W} 2 \sim \underline{\mathrm{W} 2}$ and $\mathrm{W} 3 \sim \underline{\mathrm{W} 3}$ compete. Then, in stage 3 , old varieties still exist.

Attention should be given to stage 2: the pairs of competing varieties. In this definition, the byed of Tibetan struggles with the others, rgyag and gtong. The three light verbs compete with others to the same grammatical function, and this is why we see the pairs of synonyms (see examples $39 \sim 42$ ). Thence, the contour of competing varieties will be like Table 7 as following, because of lexicon items' analogy.

Table 7. Lexicon diffusion, as proposed by Wang (1969) ${ }^{[3]}$

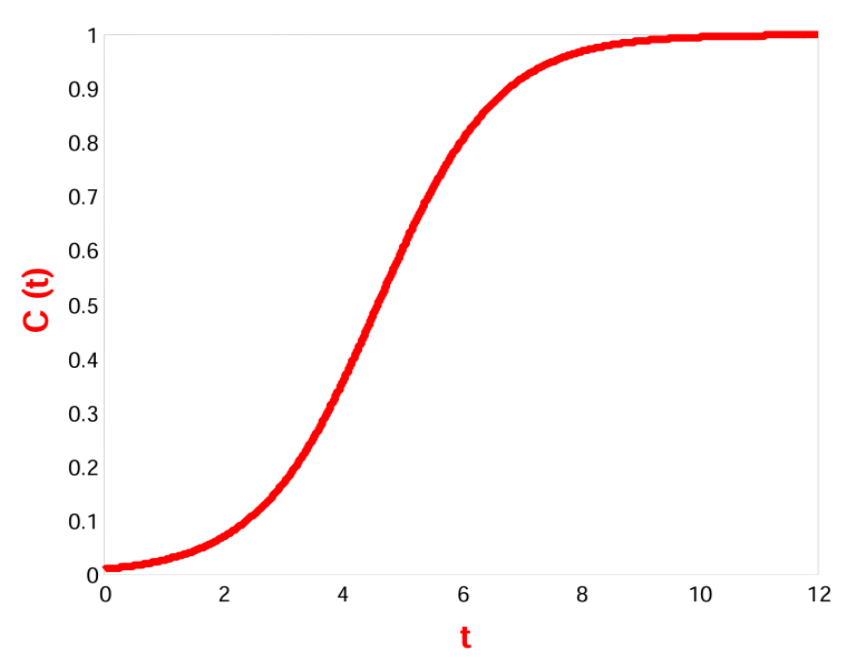

Analogy and Reanalysis are two type structure changes of language. By contrast to reanalysis, analogy is overt, and it is usually through analogy that reanalysis can be detected only (see Jäschke 1883 ${ }^{[12]}$; Wolfenden 1929 ${ }^{[19]}$; Goldstaid 2001 ${ }^{[20]}$; Brinton and Traugott 2005 ${ }^{[27]}$; Vokurková 2008 ${ }^{[21]}$; Simon \&

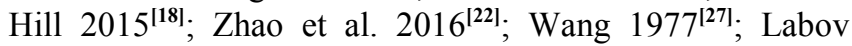
1981 $1^{[11]}$; Milroy 1992 ${ }^{[5]}$; Murray1996 $6^{[6]}$; Bybee 2002 $2^{[8]}$, $2010^{[9]}$; Kiparsky 2008 $8^{[10]}$; Bickel and Nichols 2001 ${ }^{[28]}$; Matsumoto. $2003^{[29]}$ ).

Table 8. Major components of analogical reasoning

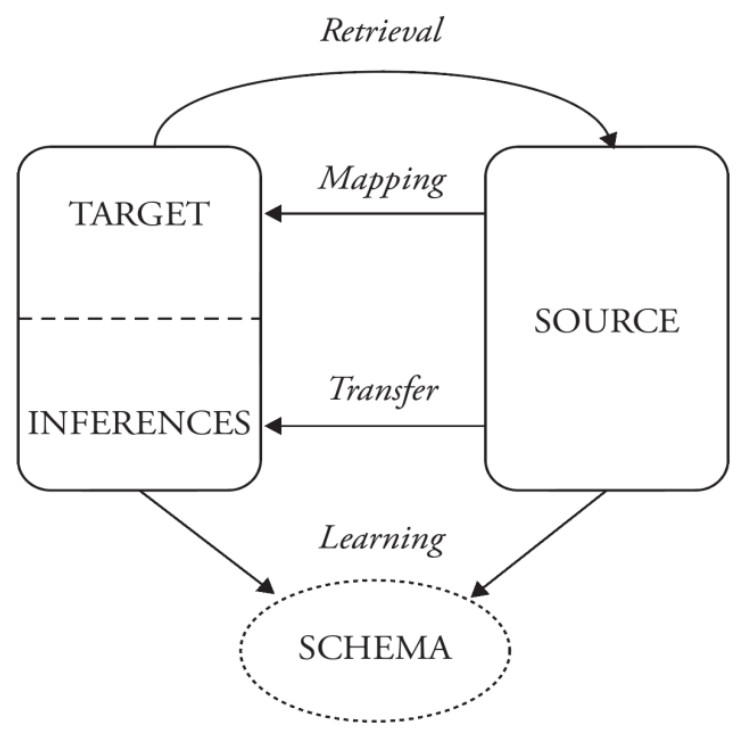

However, analogies are often used in everyday problem solving and creative cognition. Analogy is the generalization of a structure to a better-understood one. People may use some legal precedents which base on past cases to help decide a new case. Table 8 by Holyoak (2012: 236) ${ }^{[30]}$ shows that major components of analogical reasoning.

It is so-called analogical reasoning, by using a retrieval cue of known source to reason and establish a set of systematic correspondences to apply to any targets which map the relationship. Analogical reasoning explains how people create lots of constructions with which are never used and why languages are productive as well as universal.
20.
lta rtog byed
'to take care of'

\section{Residue between Lexicalization and Grammaticalization}

If we come back and focus on the byed construction as Huang (2014) $)^{[31]}$ proposes, we notice that some of them are already verbs before adding another verb. And then after adding the byed, the semantics and syntactical functions do not even changed.

Such as in example 20, lta rtog, of lta rtog byed in Zhang $(1993: 1081)^{[24]}$ is originally a verb. As Zhang shows, there are two objects which appear with lta rtog. The first one is 
phru gur lta rtog 'to take care of child' and the other is nad par lta rtog 'to take care of patient'. And even more, the traditional Tibetan case maker LA may proceeded in the environment of lta rtog, such as in rgyal la lta rtog tang 'to keep watch on something'.

When byed attaches to lta rtog, it focuses on the agent and the action of the promoter. In this way, the real semantical and syntactical function of byed just fades bit by bit. Then byed finally turns into a light verb. It is evident that this is a grammaticalizaton process. This following process applies to example 20 and it explains what happens.

Table 9. Grammaticalization process of byed

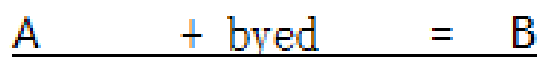

\section{A (Verb) + byed $=$ B (Verb)}

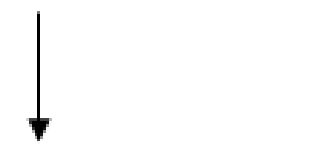

Ax

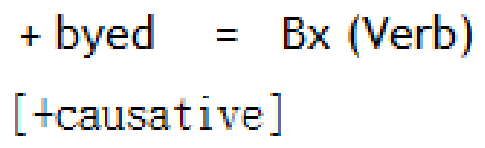

It interested us when the example is put into this development and the theory of Brinton and Traugott $(2005)^{[27]}$. Furthermore, from the scope of the lexicon diffusion proposed by Wang $\left(1969^{[3]}, 1979^{[4]}\right)$ just explains the diachronic development and of byed, rgyag and gtong.

In the beginning, byed, rgyag and gtong were different full verbs. As the change occurred, byed, rgyag and gtong show as light verbs. Recently the development of merge into light verbs took place. Hence, the byed, rgyag and gtong light verbs serve as identical one in the following examples.

$\begin{array}{lll}\text { 43a. } & \text { sgul skyod rgyag } & \text { 'to move, to act' } \\ \text { 43b. } & \text { sgul skyod gtong } & \text { 'to shake' } \\ \text { 43c. } & \text { sgul skyod byed } & \text { 'to budge' }\end{array}$

In example 43, lexicons are semantically similar but they all differ with each other. sgul skyod with the rgyag means 'to move, to act' in 43a, and sgul skyod with the gtong means 'to shack' in 43b. Finally, sgul skyod with the byed means 'to budge' in $43 \mathrm{c}$.

44a. rgyab bshad rgyag 'to discuss someone behind him / her'
44b. rgyab bshad gtong 'to discuss someone behind him / her'

44c. rgyab bshad byed 'to discuss someone behind him / her'
However, we see that the three light verbs have the same semantical meaning and grammatical function. The set from example 44 is the same as the set from example 43, with the byed, rgyag and gtong light verbs.

In Spoken Standard Tibetan, byed, rgyag and gtong still differ. However, once a grammatical development triggers, the byed, rgyag s and gtonges compete and merge to serve the same kind of grammatical function. In example 43, it is a beginning of grammatical change for byed, rgyag and gtong being almost synonyms, and then they finally merged to turn into to real synonyms.

Table 10. The merging tendency of the byed, rgyag and gtong light verbs in Spoken Standard Tibetan

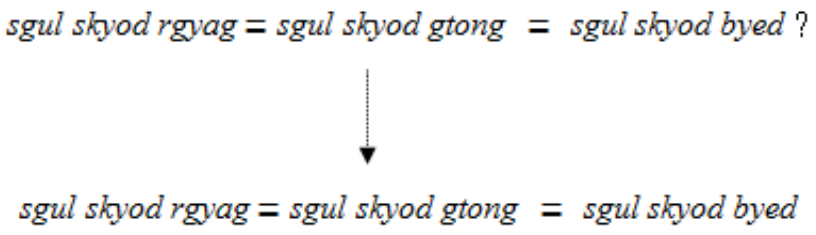

\section{Conclusions}

This paper discusses two processes, lexicalization and grammaticalization. By looking at the case of slob sbyong byed, 'to study, to learn', the formation of byed is distinguished between Old / Written Tibetan and Spoken Standard Tibetan. At the first, lexical formation (compounds) involved, and then grammaticalization began. Spoken Standard Tibetan's slob sbyong byed 'to study, to learn' is a typical example of expanding a light verb after compounding.

In Written Tibetan originally, slob 'to learn, to teach' and sbyong 'to imitate, learn, teach' were both verbs. However, in Spoken Standard Tibetan, these two verbs have evidently been compounded, becoming a parallel compound and are used as a noun. In Tibetan, the verb byed has strong actor meanings of 'doing, making, engaging (vt.) and 'can do; tool; and work for' according to Zhang (1993:1893) [24]. Eventually byed which expresses an action, is also appended and turned into a verbal element. In Tibetan, the formative process of slob sbyong byed 'to learn' is quite dramatic and yet highly representative.

Dictionary-meaning, byed, rgyag and gtong still differ. However, once a grammatical development is triggered, the light verbs (byed, rgyag and gtong) begin competing and merge to form the same kind of grammatical function. In the beginning the byed, rgyag and gtong light verbs were near synonyms. Finally, they merged and turned to the real synonyms. 


\section{REFERENCES}

[1] Laurel J. Brinton and Elizabeth Closs Traugott. (2005). Lexicalization and Language Change. Cambridge: Cambridge University Press, 2005.

[2] Paul J. Hopper and Elizabeth Closs Traugott. (2003). Grammaticalization. Cambridge University Press, 2003.

[3] William S.-Y. Wang. (1969). Competing changes as a cause of residue. Language 45:9-25.

[4] William S.-Y. Wang. (1979). Language change: A lexical perspective. Annual Review of Anthropology 8:353-371.

[5] James Milroy. (1992). Linguistic Variation and Change. Blackwell

[6] Robert W. Murray. (1996). Historical linguistics- the study of language change. Contemporary linguistics: un introduction. London and New York: Longinan

[7] Bybee, Joan. (2006). From usage to grammar: the mind's response to repetition. Language 82(4): 711-733.

[8] Bybee, Joan. (2002). Word frequency and context of use in the lexical diffusion of phonetically conditioned sound change. Language Variation and Change 14: 261-290.

[9] Bybee, Joan. (2010). Language, usage and cognition. Cambridge.

[10] Paul Kiparsky. (2008). The phonological basis of sound change. Published Online: 30 JAN 2008, DOI: 10.1002/9780470756393.ch6. Copyright (C) 2003 Blackwell Publishing Ltd.

[11] William Labov. (1981), Resolving the Neogrammarian Controversy .Language, Vol. 57, No. 2. (Jun., 1981), pp. 267-308.

[12] Heinrich August Jäschke. (1883). Tibetan Grammar. LONDON: Trübner \& CO., LUDGATE HILL.

[13] Butt, Miriam. (1993). Object specificity and agreement in Hindi/Urdu. Papers from the 29th regional meeting of the Chicago Linguistics society, 80-103. Chicago Linguistics Society.

[14] Bickel, Balthasar \& Johanna Nichols. 2001. Syntactic ergativity in light verb complements. Proceedings of the 27 th Annual Meeting of the Berkeley Linguistics Society 27. 3952.

[15] Alexandros Tantos. (2008). Computing Events in Discourse: A Case Study Involving Light have. Doctoral dissertation, University of Konstanz.

[16] Melanie Seiss. (2009). On the Difference between Auxiliaries, Serial Verbs and Light Verbs. Proceedings of the LFG09 Conference Miriam Butt and Tracy Holloway King (Editors) . CSLI Publications.
[17] Miriam Butt. (2010). The light verb jungle: Still hacking away. $\mathrm{M}$ Butt. Complex predicates in cross-linguistic perspective, 48-78, 2010.

[18] Simon and Hill. (2015). 16.6 Tibetan, in Edinburgh Handbook of Evaluative Morphology. Edited by Nicola Grandi, Livia Kortvelyessy. Edinburgh University Press.

[19] Stuart N. Wolfenden. (1929). Outlines of Tibeto-Burman linguistic morphology : with special reference to the prefixes, infixes and suffixes of classical Tibetan and the languages of the Kachin, Bodo, Nâgâ, Kuki-Chin and Burma groups.

[20] Melvyn C. Goldstein. (2001). The New Tibetan-English Dictionary Of Modern Tibetan. University of California Press.

[21] Zuzana Vokurková. (2008). Epistemic Modalities in Spoken Standard Tibetan, University of Paris VIII: PhD dissertation.

[22] Weina Zhao; Lin Li; Huidan Liu; Jian Wu. (2016). Tibetan trisyllabic light verb construction recognition, Himalayan Linguistics Vol. 5(1): 137-148.

[23] Heinrich August Jäschke. (1881). A Tibetan English Dictionary. Kyoto: Rinsen Book Company.

[24] Yisun Zhang. (1993). Tibetan-Chinese dictionary, min zu chu ban she.

[25] Daoquan Yu. (1983). la sa kou yu ci dian, min zu chu ban she.

[26] Fang-Kuei Li and W. South Coblin. (1987). A Study of the Old Tibetan Inscription. Institute of Linguistics, Academia Sinica.

[27] William S-Y. Wang (ed.). (1977). The Lexicon in Phonological Change. The Hague: Mouton. 278 pages. Reviews by M. Hashimoto, Language 57.183-91, 1981; by E.G. Pulleyblank, Journal of Chinese Linguistics10.392-416, 1982.

[28] Balthasar Bickel and Iohanna Nichols. (2001). "Syntactic ergativity in light verb complements". Proceedings of the 27 th Annual Meeting of the Berkeley Linguistics Society.

[29] Yo Matsumoto. (2003). Typologies of Lexicalization Patterns and Event Integration: Clarifications and Reformulations. In Shuji Chiba et al. eds., Empirical and Theoretical Investigations into Language: A Festschrift for Masaru Kajita, pp. 403-418. Tokyo: Kaitakusha.

[30] Keith J. Holyoak. (2012). Analogy and relational reasoning. In K. J. Holyoak \& R. G. Morrison (Eds.), The Oxford handbook of thinking and reasoning (pp. 234-259). New York: Oxford University Press.

[31] Chinwen Huang. (2015). The Lexical Formation of Tibetan slob sbyong byed. the 35th meeting of Tibeto-Burman Linguistic Circle . Kyoto University. 